УДК 81’243:371.334

DOI: $10.24144 / 2617-3921.2019 .17 .249-258$

Вікторія Леган

Викладач кафедри іноземних мов ДВНЗ «Ужсгородський наџіональний університет»

ORCID 0000-0003-0222-3120

м.Ужггород, Україна viktoriya.lehan@uzhnu.edu.иа,тел.0508849380

Наталія Годованець

кандидат філософських наук,доиент дочент кафедри іноземних мов ДВНЗ «Ужсгородський національний університет»

ORCID 0000-0003-3429-6973

м.Ужгород, Украӥна nataliia.hodovanets@uzhnu.edu.иa, тел.0958789075

\title{
Дискусія як активний метод вивчення іноземних мов
}

Анотація. У статті розглянуто дискусію як активний метод вивчення іноземних мов. Описано феномен дискусії та етапи ї̈ організації. 3'ясовано, щзо головним завданням дискусії у процесі навчання $\epsilon$ стимулювання пізнавального інтересу, залучення різних точок зору в активне обговорення проблем іноземною мовою. Визначено основну роль у забезпеченні ефективності дискусії. Досягнення мети якої відбудеться тільки за умови дотримання всіма ї̈ учасниками певних правил. Під час планування дискусї потрібно враховувати кілька важливих моментів: мету, час та чіткість організаиї̈ дискусії.

Ключові слова: дискусія, метод, іноземна мова, правила, мета, навчання.

Abstract. In a given article a discussion as an active method of learning of foreign languages is considered. The phenomenon of discussion and stages of its organization are described. It is found out that the main task of a discussion in the course of teaching is stimulation of cognitive interest, involving various points of view in active discussion of problems in a foreign language. The main role in ensuring efficiency of a discussion is defined. Achieving the goal of which will occurs only on condition of observance by all its participants of certain rules. During planning a discussion it is necessary to take into account several important points: the purpose, time and also the clarity of the organization of a discussion. The discussion requires students not to give simple answers to questions, but on the contrary - to express their own opinions. The method of discussion can be used at the stage of assimilation of knowledge, in the course of consolidation and 
systematization. This method of teaching is aimed at the development of critical thinking and communicative abilities.

Keywords: discussion, method, foreign language, rules, purpose, teaching.

Актуальність досліджуваної у статті теми визначається сучасними, ефективними методами у вивченні іноземних мов, завдяки комунікативному та діяльнісному підходу, а саме дискусії. Позаяк особистісна орієнтація та критичне мислення у сучасному суспільстві $€$ невід'ємною складовою освітнього процесу, дискусія сприяє розвитку особистості та оволодіння навичками спілкування іноземною мовою.

Вступ. Методологія навчання у вищій школі відрізняється від методології навчання середньої школи. Сутність вибору відповідних методів полягає не тільки в передаванні та сприйнятті знань, але й у проникненні у процес розвитку науки з розкриттям іiі методологічних основ.

3 огляду на свою специфіку методи навчання й методи учіння відносно самостійні, але розглядати їх слід тільки в єдності. Ефективна навчальнопізнавальна діяльність студентів в основному залежить від уміння викладача/вчителя вдало вибрати й застосовувати відповідні методи та прийоми навчання іноземної мови, а також вміло підібрати відповідних навчальний матеріал.

Учений-педагог Ю. Бабанський запропонував свою власну класифікацію:

а) методи організації й здійснення навчально-пізнавальної діяльності (пояснення, інструктаж, розповідь, лекція, бесіда, робота 3 підручником; ілюстрування, демонстрування, самостійне спостереження, вправи, лабораторні, практичні і дослідні роботи);

- б) методи стимулювання навчальної діяльності (навчальні дискусії, створення ситуації інтересу у процесі викладення, створення ситуації новизни, опора на життєвий досвід студента; стимулювання обов' язку й відповідальності в навчанні);

в) методи контролю i самоконтролю у навчанні (усний, письмовий, тестовий, графічний, програмований, самоконтроль і самооцінка) [1].

\begin{tabular}{|l|l|l|}
\hline $\begin{array}{c}\text { Основні групи } \\
\text { методів навчання }\end{array}$ & $\begin{array}{c}\text { Основні підгрупи методів } \\
\text { навчання }\end{array}$ & $\begin{array}{c}\text { Окремі методи } \\
\text { навчання }\end{array}$ \\
\hline 1 & 2 & 3 \\
\hline $\begin{array}{c}\text { 1. Методи } \\
\text { стимулювання і } \\
\text { мотивації учіння }\end{array}$ & $\begin{array}{c}\text { 1.1. Методи формування } \\
\text { інтересу до учіння }\end{array}$ & $\begin{array}{c}\text { Пізнавальні ігри, } \\
\text { навчальні дискусії, } \\
\text { методи емоційного }\end{array}$ \\
\hline
\end{tabular}




\begin{tabular}{|c|c|c|}
\hline & & стимулювання та ін. \\
\hline & $\begin{array}{l}\text { 1.2. Методи формування } \\
\text { обов'язку і відповідальності } \\
\text { в учінні }\end{array}$ & $\begin{array}{l}\text { Методи навчального } \\
\text { заохочення, осуду, } \\
\text { пред'явлення } \\
\text { навчальних вимог та } \\
\text { ін. }\end{array}$ \\
\hline \multirow{3}{*}{$\begin{array}{l}\text { 2. Методи } \\
\text { організації і } \\
\text { здійснення } \\
\text { навчальних дій та } \\
\text { операцій }\end{array}$} & $\begin{array}{l}\text { 2.1. Перцептивні методи } \\
\text { (передачі і сприймання } \\
\text { навчальної інформації за } \\
\text { допомогою органів чуттів) }\end{array}$ & \\
\hline & Словесні методи & $\begin{array}{l}\text { Лекція, розповідь, } \\
\text { бесіда тощо }\end{array}$ \\
\hline & Наочні методи & $\begin{array}{l}\text { Методи ілюстрацій, } \\
\text { демонстрацій, } \\
\text { кінопоказу тощо }\end{array}$ \\
\hline
\end{tabular}

Табл.1 Системна класифікація методів навчання (за Ю. Бабанським)

За основу цієї класифікації взято розв'язання не одного дидактичного завдання (наприклад, розвиток творчої самостійності в учінні), а всіх основних завдань освіти, виховання i розвитку особистості: розвиток теоретичного й емпіричного мислення, навичок практичної діяльності, самостійної роботи, формування світогляду тощо.

Традиційні методи навчання - форма інформаційно-рецептивного навчання, що має репродуктивний характер і спрямована на передачу певного масиву знань, формування навичок практичної діяльності. До традиційних належать: лекції, семінари, практичні заняття і т. п. Завдяки ним студенти вивчають заданий матеріал і відтворюють його при контролі. Активні методи навчання - це способи активізації навчально-пізнавальної діяльності студентів, які спонукають до активної розумової і практичної діяльності в процесі оволодіння матеріалом, коли активний не тільки викладач, але й студент [2].

Диференціюють імітаційні та не імітаційні методи активного навчання. Базуючись на ознаках інтерактивного навчання, форми й методи такого навчання можна розділити на дискусійні (інтерактивна лекція, діалог, групова дискусія, дебати, проведення навчальних клінічних конференцій тощо), ігрові (ділові, рольові, освітні), тренінгові форми проведення занять (комунікативні, особистісного зростання, професійні) [7]. 
База даних, методи та методологія проведення дослідження. Для вивчення та розуміння дискусії вже існує низка методів та підходів, які допомагають краще зрозуміти та дослідити це явище комунікативного навчання. У процесі дослідження ми послуговувались методами дескриптивного аналізу та узагальнення, синтезу, а також соціальним, психологічним та когнітивним підходом. Спираючись на представлені методи слід зазначити, що дискусія вимагає активної участі всіх учасників процесу, допомагає проявити власну позицію та координує процес критичного мислення. Проаналізувавши проведення дискусії було виявлено декілька етапів даної форми навчання, а саме підготовку (вибір теми, визначення мети, розробка питань, підготовка учасників, організація процесу), хід( питання, виступи, обговорення) та підсумки. Також зазначимо, що педагог повинен пам'ятати про мету, час та підсумки проведеної дискусії для забезпечення максимального результату.

Виклад основного матеріалу. Феномен дискусії бере початок 3 30-х років. Саме психологи звернули увагу на дискусію в своїх роботах, вказавши, що людина завдяки механізмам дискусій відходить від симетричного мислення і вчиться приставати на точку зору інших. Найбільш поширені області застосування дискусії: активні методи навчання, соціальнопсихологічний тренінг, методи виявлення лідера і оцінки компетентності керівника, способи вирішення конфліктів; терапія межових психічних станів тощо. Конкретні форми і прийоми дискусії обумовлені завданнями групової діяльності і зазвичай їх поділяють на методи аналізу конкретних ситуацій i методи групового самоаналізу. Саме цей метод навчання, спрямований на розвиток критичного мислення i комунікативних здібностей, припускає цілеспрямований i впорядкований обмін думками. При цьому він орієнтований на узгодження протилежних точок зору. В основі дискусії лежить суперечність, яка відображає протилежні погляди учасників на той самий предмет обговорення. Процес організації дискусії охоплює декілька етапів:

1 - явне визначення тези і антитези (як результат критики в складній комунікаціі);

2 - надання кожною стороною аргументів, що підтверджують i підсилюють точку зору;

3 - надання кожною стороною підстав;

4 - фіксація труднощів і постановка проблеми;

5 - пошук нових підстав, способів рішення, поглядів на предмет;

6 - синтез.

Головне завдання дискусії у процесі навчання - стимулювати пізнавальний інтерес, залучати різні наукові точки зору учнів/студентів в активне обговорення різних проблем, спонукати їх до осмислення різних підходів та аргументації чужої і власної позиції іноземною мовою. Дискусія 
без знання стає безпредметною, беззмістовною й неточною, а без уміння виражати думку, переконати опонентів, - позбавлена привабливості, заплутана й суперечлива. Навчальна дискусія, 3 одного боку, допускає наявність у студентів уміння ясно й точно формулювати власні думки, будувати систему чітких доказів, з іншого - вчить їх мислити, сперечатися, доводити свою правоту. Педагог повинен власним прикладом демонструвати перед студентами зразок стилю аргументації, навчати точно висловлювати свої думки й толерувати формулювання інших учнів-студентів. Дискусія $€$ дієвим методом обговорення питання, яке пропонують вивчити, а також це колективне обговорення деякої проблеми, під час якого досягається іiі вирішення.

«Сутність дискусії, - на думку Ч. Купісевича, - полягає в обміні думками на певну тему між учителями й учнями або тільки між учнями» [3,c.142]. Дані думки можуть бути власними, а також посилатися на погляди інших людей. Ефективна дискусія - це різноманіття думок, можливість та потреба відшукати найбільш вдалий варіант розв'язання дидактичної проблеми й активна участь у ній респондентів. У порівнянні з лекціями та бесідами вони створюють найбільш сприятливі умови для активізації студентів і впливу на їхню психіку, зокрема на творчу уяву та фантазію. Дискусія вимагає від учнів/студентів не простих відповідей на запитання, а навпаки - обгрунтованих, емоційно забарвлених та змістовних варіантів розв'язання дидактичних проблем, чіткого висловлювання власних думок. Даний вид обговорення викликає позитивні емоції також в учасників, сприяє виникненню різних групових соціально-психологічних явищ, виявляє навички колективної роботи й уміння вислухати думки та точки зору інших учнів. Різновиди навчальних дискусій можна застосовувати під час дидактичної роботи з різними категоріями учнів та студентів університетів [3].

Дискусії й обговорення можна проводити цілою групою. Однак вони набагато ефективніші, коли їх проводять у підгрупах, зокрема, якщо група велика, а час обмежений. Групове обговорення максимально підвищує активність і внесок кожного учасника. Дискусія допомагає учням/студентам уточнити свої уявлення, усвідомити почуття і ставлення. Обговорення у групах дає змогу більше дізнатися одне про одного, стимулює вільний обмін думками, збільшує ймовірність того, що учні/студенти краще зрозуміють почуття і позиції інших, більше зважатимуть на них. Робота у групах розвиває навички активного слухання, співпереживання, співпраці, впевненої поведінки і толерантності.

В. Оконь пропонує три види дискусії:

- «побіжна» (виникає стихійно під час розгляду та обговорення складних питань, які цікавлять більшість учнів);

- дискусія, спрямована на формування переконань; 
- справжня навчальна дискусія (спеціально організовується для розгляду важливої дидактичної проблеми) [5].

Методика проведення дискусії поділяється на три етапи: перший педагог повинен зацікавити учнів проблемою дискусії, другий - обговорення власне дидактичних проблем, третій - підсумки й формулювання висновків.

Основна роль у забезпеченні ефективності дискусії надається правилам iii ведення. Творча ініціатива педагога та активна участь учнів/студентів мають вирішальне значення. Дидактично-виховної мети дискусії буде досягнуто тільки за умови дотримання всіма ii учасниками таких правил:

1. точне визначення навчальної проблеми, що підлягає обговоренню;

2. докладне уявлення про методи, прийоми і способи ії розв'язання;

3. чітке визначення змісту понять, термінів і категорій, які використовуватимуть учасники дискусії;

4. обов’язкове обгрунтування власної позиції;

5. можливість відкритого висловлювання своїх думок і шанобливе ставлення до опонентів та їхніх поглядів [1].

Педагог повинен поступово вчити учнів/студентів умінню обгрунтовано дискутувати, вагомо аргументувати на захист своєї позиції, розмірковувати принципово, відкрито, невимушено, в умовах поваги до опонента та його поглядів.

Дискусія є важливим засобом пізнавальної діяльності учнів/студентів у процесі навчання іноземної мови. Дискусія навчає чути й розуміти співрозмовника, сприяє уточненню власних переконань, формуванню особистого погляду на зовнішній світ. Учені-дидакти відносять дискусію як до методів навчання, так і до форм організації навчання. Дехто 3 фахівців бачить дискусію як форму співробітництва, коли щодо обговорюваної проблеми висловлюються усі учасники спільної діяльності. Метод дискусії можна застосовувати на етапі засвоєння знань, в процесі їхнього закріплення та систематизації. Крім того, дискусія застосовується як метод розвитку психічних функцій, творчих здібностей та особистісних якостей учнів/студентів, а також як метод стимулювання й мотивації осіб які беруть участь у навчальному процесі. Власне у процесі використання дискусії під час навчання іноземної мови можна сформулювати певні організаційнопедагогічні підвалини, спільні для будь-яких різновидів дискусії: проведення дискусії необхідно починати 3 постановки конкретного питання для обговорення (тобто такого, яке б не мало однозначної відповіді й пропонує різні варіанти вирішення, особливо протилежні); усі висловлювання не мають виходити за межі заданої обговорюваної теми; кожне з висловлюваних тверджень повинне супроводжуватись аргументацією. [8]

Учитель/викладач може ставити певні навідні питання на зразок: “Які факти свідчать на користь цієї думки?”, “Яким чином ви дійшли такого висновку?"; дискусія може завершитися як консенсусом (прийняттям узгодженого, спільного рішення), так i збереженням представлених 
розбіжностей між учасниками дискусії. У проведенні дискусії використовуються різні організаційні методики:

1. Методика «Питання - відповідь». Представлена методика - це різновид співбесіди; відмінність полягає в тому, що застосовується певна форма постановки питань для співбесіди з учасниками дискусії - діалогу.

2. Методика «Обговорення напівголосно». Дана методика полягає у проведенні закритої дискусії в мікрогрупах, після чого проводиться загальна дискусія.

3. Методика «Клініки». За використанні «методики клініки» кожен 3 учасників розробляє свій варіант рішення, попередньо представивши на відкрите обговорення свій варіант вирішення поставленої проблемної ситуації, потім це рішення оцінюється як керівником, так і спеціально виділеної для цієї мети групою експертів за бальною шкалою або заздалегідь прийнятої системи «приймається - не приймається».

4.Методика «Лабіринту». Даний вид дискусії ще називають методом послідовного обговорення, він являє собою своєрідну покрокову процедуру, в якій кожен наступний крок робить інший учасник дискусії. Обговоренню тут підлягають усі рішення, навіть невірні (тупикові).

5.Методика естафети .Кожен учасник, який припинив виступати може передавати слово тому, кому вважає за потрібне.[6]

Під час планування дискусії педагог враховує кілька важливих моментів: час, необхідний для іiі проведення, матеріали, необхідні для роботи та наочного подання їі результатів. Упродовж усієї роботи учитель тримає в полі зору такі моменти: мета, від якої не слід відхилятися; час, якого слід дотримуватись; чіткість організації вступної частини дискусії, оскільки саме вона створює емоційний та інтелектуальний настрій дискутування. Відповідно до логіки застосування дискусії як методу закріплення навчального матеріалу i стимулювання пізнавальної діяльності учнів/студентів, можна визначити кілька варіантів моделювання навчальних тем на основі дискусії: вивчення теми як підготовки до дискусії, яка має відбутися на занятті; внесення дискусійного компонента в окремі заняття на етапах перевірки домашнього завдання та закріплення щойно вивченого матеріалу; навчання у формі самостійної або групової роботи учнів/студентів 3 подальшим обговоренням отриманих результатів. Це дає змогу студентам оволодіти додатковим лексичним матеріалом 3 іноземної мови, спонукає до мовленнєвої інтенції, а саме до процесу формування думки іноземною мовою та підбору потрібних слів. Проведення дискусії вимагає ретельної підготовки: тема повинна бути сформульована проблемно, аби підходи до їі висвітлення були різновекторними; слід врахувати рівень володіння іноземною мовою та заздалегідь оголосити план аби учні/студенти могли підготуватися: опрацювати літературу, підготувати нотатки тощо. Дослідження, проведені Національним тренінговим центром (США, штат Меріленд) у 1980-х роках, показують нам, що інтерактивне навчання 
уможливлює різке збільшення відсотка засвоєння матеріалу, бо впливає не лише на свідомість учня, а й на його почуття, волю. Результати цих досліджень відображено у схемі, яка дістала назву «Піраміда навчання».

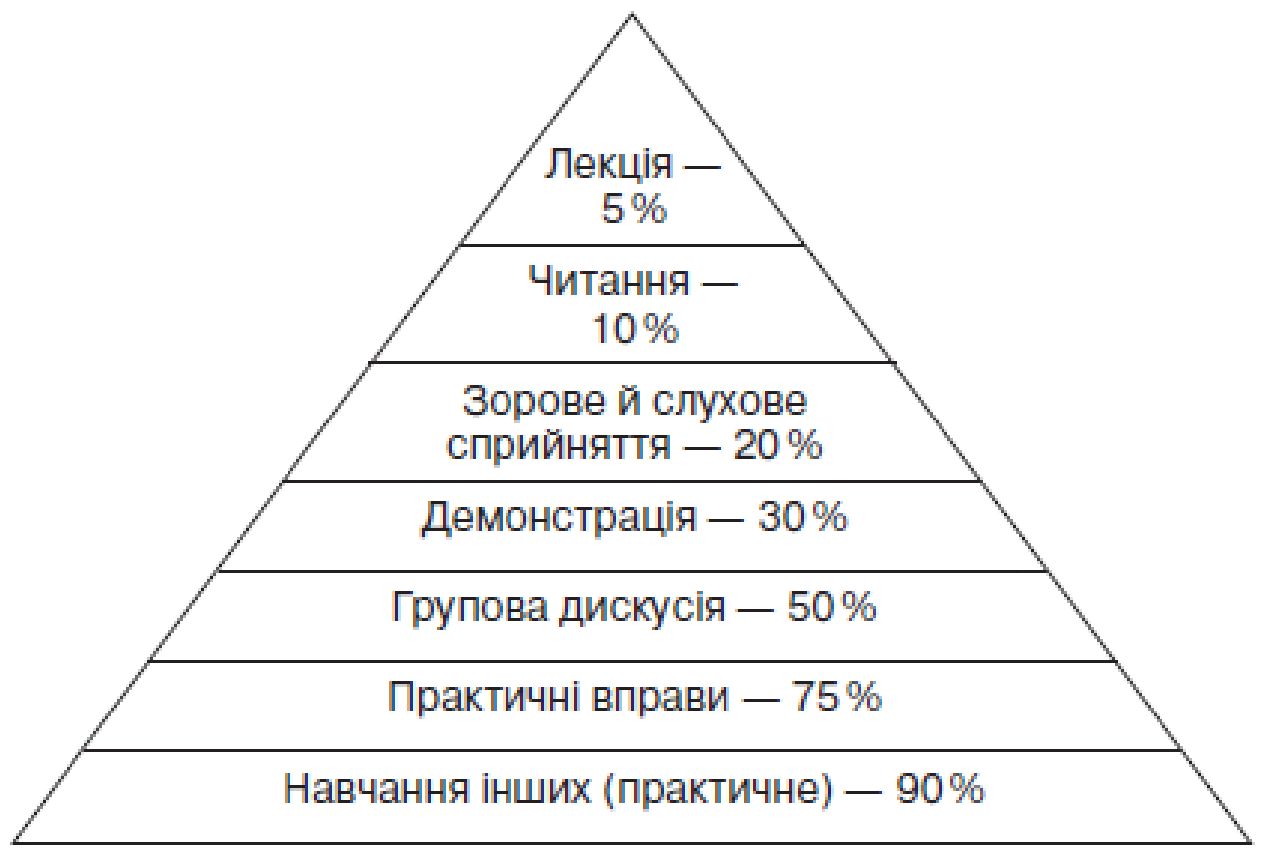

Піраміда навчання

3 представлених даних піраміди видно, що найменших результатів можна досягти за умов пасивного навчання (лекція $-5 \%$, читання $-10 \%$, зорове і слухове сприймання - $20 \%$, демонстрування - $30 \%$ ), а найбільших інтерактивного (групова дискусія - 50 \%, практичні вправи - 75 \%, навчання інших або негайне застосування знань - 90 \%).[4] Ці дані $\epsilon$ середньостатистичними, тому в конкретних випадках результати можуть різнитися, але в середньому таку закономірність може простежити кожен педагог. Ще краще, якщо ми можемо щось "зробити" з інформацією, щоб отримати зворотній зв'язок, чи добре ми іiі зрозуміли. Наприклад з цією метою можна: викласти інформацію своїми словами; навести свої приклади; показати певні подібні прояви, подібні ознаки в інших явищах і процесах; знайти зв'язок 3 іншими процесами або явищами, вже відомими раніше; передбачити деякі наслідки; знайти протилежності.

\section{Висновки}

Сучасний педагог у навчально - виховному процесі повинен намагатися вдосконалювати свою роботу, використовувати нові форми, методи та прийоми на заняттях. Саме тому вчитель/викладач має розглядати кожного учня/студента як окрему особистість 3 поглядами, переконаннями, почуттями.

Застосування активних методів навчання іноземної мови $\epsilon$ інноваційним процесом спрямованим на формування комунікативних здібностей учнів/студентів, а також на розвиток самостійності їхнього 
мислення у створених умовах. Методи інтерактивного навчання можна умовно розділити на: дискусійні (діалог, групова дискусія, рольова дискусія, розбір ситуацій з практики, аналіз ситуацій морального вибору, метод «круглого столу», колективні рішення творчих завдань); ігрові(дидактичні і творчі ігри, ділові та рольові ігри, організаційно-діяльні); тренінгові(проведення занять, які можуть включати в себе дискусійні та ігрові).

Дискусія значною мірою сприяє розвитку критичного мислення, а також дає можливість визначити власну позицію, формує навички відстоювання своєї думки, сприяє поглибленню знань 3 обговорюваної проблеми, поглибленню та збагаченню словникового запасу 3 іноземної мови. Сучасна дидактика визнає велику освітню і виховну цінність дискусії адже вона сприяє глибокому розумінню обговорюваної проблеми. Отже створення даного виду мовленнєвої діяльності на заняттях іноземної мови спонукає усіх учнів/студентів залучатися та висловлюватися на задану тематику використовуючи знання тісї чи іншої іноземної мови. А використання дискусії як методу навчання сприяє самоствердженню та самовираженню студента у процесі комунікації з дорослими та молодими людьми з інших країн без страху мовного бар'єру.

Питання дискусії $є$ перспективним, адже розвиток сучасного суспільства та глобальна інтеграція потребує сучасних підходів у вивченні іноземних мов та вибору активних і дієвих методів навчання серед яких власне і представлена дискусія.

\section{ЛІТЕРАТУРА}

1. Бабанский Ю. Методы обучения в современной общеобразовательной школе. Москва: Просвещение, 1985. 208c.

2. Кашлев С. Технология интерактивного обучения. Минск: Белорусский всрасень, 2005. 196с.

3. Куписевич Ч. Основы общей дидактик. Пер. с польск. О. В. Долженко. Москва: Высшая Школа, 1986. 142с.

4. "Модуль 3. Методологія Викладання Курсу «Вчимося Жити Разом» Індикація Модуля, в Якому Знаходиться Користувач." 3.3. Огляд Інтерактивних Методів, 1lt.multycourse.com.ua/ua/page/19/67. 12.06.19

5. Оконь В. Основы проблемного обучения. Москва: Просвещение, 1968. $208 \mathrm{c}$.

6. Пометун О., Пироженко Л. Інтерактивні технології навчання: теорія, практика, досвід. Київ: А.П.Н, 2002. 135с.

7. Січкарук О. Інтерактивні методи навчання у вищій школі. Київ: Таксон, 2006. 88c. 
8. Топтигіна Н. Навчання дискусії на матеріалі художніх текстів у процесі вивчення англійської як другої іноземної мови. Дис. КНІУ, 2004. Київ: КНIУ. 307c. 